\section{$35 t$}

\section{COCOA DISEASE IN}

$\mathrm{F}^{\circ}$ R some years past, increasing uneasiness has been felt about the future of pocoa in West Africa and particularly in the Goldforast. Trees began to die in ever-increasing numbers, and at first the trouble was attributed/to of ifophek' and physiological troubles, due to the exesy removal of high forest which occurred dueng the rapid opening up of the country for new plawtations. This it was believed let in the dry 'harmattan' winds from the Sahara, causing a less favourable environment for the cacao tree. As a remedial measure the establishment of shelter belts of high forest was recommended, and in due course they came into being ; but the trouble still continued to spread and remained an unsolved puzzle until one of the scientific officers, stationed on the newly opened Cacao Research Station, established that the cause is a virus disease. The research station is situated at Tafo in the middle of one of the badly infected areas of the Eastern Province, and was opened about ten years ago. It has done valuable work in establishing that several types of virus are responsible, that infection is conveyed by particular species of mealy bugs, and that certain species of indigenous forest trees can serve as alternative hosts.

The Station has also devoted much attention to methods of control and has come to the conclusion that the basic method for dealing with a disease of this type is the removal of sources of infection. This means cutting out not only trees that are obviously beyond hope of recovery, but also trees that show symptoms of the disease but are still bearing some fruit. Most of the cocoa farmers are poorly educated men, with only two or three acres apiece, and it naturally went against the grain to ask them to destroy trees that were apparently still capable of producing a few pods, especially at the present time when prices are exceptionally high. Attempts to apply this 'cutting out' cure have been unpopular and have been strongly resisted by the growers. Unfortunately also, local politics were dragged in, so that serious disturbances took place in March 1948, with the result that the legal powers to compel cutting out, which already exist, have not been enforced. For nine months or more the disease has to all intents and purposes been allowed to spread unchecked, for the cutting out campaign has been suspended.

As a consequence of these events, a special com. mission was sent out by the Colonial Office in May 1948 to report on the disturbances, and acting on one of its recommendations, a panel of three plant pathologists of international repute, drawn from countries not commercially interested in cocoa growing, was selected to study the disease and report on its control or eradication. These men were appointed to the commission after consulting the United Nations Food and Agriculture Organisation, and their report has now been issued*, giving an entirely independent and up-to-date account of the cocos position in the Gold Coast. In the first place, they entirely endorse the conclusion reached some years ago by the West African Cacao Research Station at Tafo, that cutting out is, at present, the only practical control measure. They point out the magnitude of the problem involved, as this means

- Colonial Office: Report of the Commission of Enquiry into the Swollen Shoot Disease of Cacao in the Gold Coast. (Colonial No. 236.) Pp. 10. (London: H.M. Stationery Office, 1948.) 3d. net. cutting out at least fifty million diseased cacao trees and several million wild host trees. Nobody knows how many cacao trees there are in the Gold Coast, but the figure may be of the order of 400 million; under these proposals, therefore, it seems probable that one-eighth of the existing cacao trees would have to go. So far, under the existing voluntary cutting-out scheme, not more than three million trees have been removed.

The urgency of the problem is emphasized since the disease is spreading at the rate of fifteen million trees a year, and has recently made great headway, because control measures have practically ceased since the March riots. The Eastern Province was the first area affected, and large blocks of cacao have been killed in what was formerly the most productive cocoa belt. The disease has spread to Ashanti, where former isolated outbreaks have extended to an alarming degree. The Western Province is still more or less in the period of sporadic outbreaks, but there is every prospect of its following the other two provinces unless adequate measures are taken. The Commission points out that far more vigorous action will have to be taken if there is to be any hope of saving the industry. Not only will the staff of the Agricultural Department need to be greatly strengthened, but means will have to be taken to bring home to all sections of the public the urgency of the matter and the definite threat to the whole industry, on which depends ultimately the prosperity of the entire country; for the Gold Coast relies to a frightening extent on the revenue obtained from its cocoa crop.

The Commission recommends, therefore, that the first and most important task is to educate all classes of the population to the seriousness of the position, and to secure their support for the 'cutting out' campaign. Until public opinion has been educated up to this point, it will not be easy to carry out the drastic campaign envisaged. It must be remembered that cocoa in the Gold Coast is produced by many thousands of peasants farming two or three acres each, or working land belonging to absentee landlords. The majority of these men are illiterate, and the difficulty will be to bring home to them the facts of the case. Something can be done by an extension of the radio system to the villages and markets; but the best way is probably personal conversation with a representative of the Government. Even a greatly enlarged staff in the Agricultural Department could only contact a small proportion, and it will be necessary for the campaign of enlightenment to be carried on by members of all Government departments, native authorities and chiefs' councils, and the Press.

It is obvious that, for the cutting-out programme to be effective, it must not only be vigorous but also thorough. It will be useless to treat most of the fields in an area and leave two or three untreated plots because the owners refuse to co-operate. These plots will be the cause of rapid re-infection of the neighbouring fields. Eventually it is hoped that public opinion will insist that all must play their part for the general good. It is obvious, however, that time will be needed to reach such a desirable state of affairs, and the need for a publicity campaign emphasizing the vital stakes at issue is all the more urgent. 
While endorsing the control methods of the Cacao Research Station, the Commission is inclined to think that the method of cutting out may need to be even more stringent if the disease is to be eradicated permanently from a particular area. It is pointed out that it is not sufficient merely to cut out trees showing signs of the disease; neighbouring trees that are in contact are also probably diseased, although they may not show symptoms until a later stage. The contact trees, therefore, will also have to go. It will be difficult to persuade the peasant farmer to cut out an apparently healthy tree by assuring him that it is the only way that his crop can be saved in the future. Since only a vigorous and thorough removal of infection sources can be expected to achieve a reasonable degree of success, the Commission thinks it advisable that the limited staff at present available should concentrate its efforts in areas of lesser infection, particularly Ashanti and the Western Province.

It may be that eventually the so-called 'raging belt' area of the Eastern Province, where the cacao fields have been practically wiped out, may prove to be the best place to resuscitate the industry, and at the same time replace the old methods by something more in keeping with the present time. In this area large areas of cacao have ceased to exist-only here or there a few trees struggle on. With the cooperation of the chiefs and their peoples, it might be possible to start new plantations on modern lines. This would entail the planting of cacao in large compact units instead of thousands of small scattered plots as at present. The area selected would have all existing cacao and wild host trees completely removed, and be left fallow for two or three years before replanting. The new area would be planted in rows at the most desirable distance apart, and this would enable spraying machinery to be worked if at any time action was needed in the future. At present, Gold Coast cacao is planted in a most haphazard way, and it is impossible to get into the crop to spray or prune.

A plantation of the type envisaged would have a relatively small periphery for its acreage, and border control of invasion from outside should be comparatively easy. There would be difficulties over land tenure and other customs, and these would have to be the subject of careful consideration and of goodwill on the part of the village authorities.

The fact remains, however, that one cannot envisage the Gold Coast succeeding in reviving its cocoa industry by relying on the old happy-go-lucky methods. There would be no guarantee that a crisis similar to the present one might not again arise. It is unimaginable that a disease of this nature could have got out of hand in this way if the erop had been properly cultivated and organised on a more rational basis. The present calamity that has befallen the Gold Coast cocoa crop may in the end, therefore, prove a blessing in disguise. If the growers are wise, they will take the opportunity of putting their industry on a sound basis. They will learn to treat their cacao as an orchard crop and not as a bit of jungle.

The establishment of plantations on the lines mentioned will enable modern up-to-date methods to be employed and better material planted. The research workers must have time to make their investigations ; but already there are signs that higher-yielding, disease-resistant varieties may be forthcoming, and better methods of cultivation, fertilizing and disease control become available.
The Commission points out with reason that inadequate attention to the situation up to the present has allowed the disease to gain such headway that effective and immediate action is needed. One of the problems that as yet remains unsolved is the extent to which wild trees and plants are alternative hosts. It is known that the silk cotton tree, the cola and three or four species of Sterculiaceæ are carriers of the virus; but there may be others, and the search is still being continued. The destruction of some of these trees will present a big problem, for many of them are giants of $200 \mathrm{ft}$., with buttressed roots rising to $30 \mathrm{ft}$. in height. The possibility of destroying them by chemical means is being considered, but even so the task of killing several millions of such trees will be a stupendous one. The replanting of lightly affected areas will also prove difficult. It seems that more preliminary work is needed to ascertain the margin of time when it can be deemed safe to replant in lightly affected areas, from which a few diseased trees have been removed. Young cacao trees apparently show few signs of disease for the first three or four years, but after that, when their canopies become contiguous, they may become reinfected unless a complete sweep has been made of all possible sources of mealy bug infection.

The best hope for the future lies in continued research on the lines indicated in the report, coupled with a determination to re-establish the industry on rational lines; and for the present to attempt to alleviate the existing crisis by intensifying the 'cutting-out' campaign. GEOFFreY EVANS

\section{RECENT ADVANCES IN THE CHEMISTRY OF HYDROCARBONS*}

\author{
By D.S. F. BIRCH \\ Research Station, Anglo-Iranian Oil Co., Ltd.
}

$T$

HE demand for highly branched isoparaffins for use in higher-performance aviation fuels has stimulated research during the last ten to fifteen years into methods for producing such hydrocarbons in large quantities from available raw materials. Ot the processes resulting from this work those based on isomerization and on alkylation are of outstanding importance.

In the isomerization process the molecular struc. tures of the paraffins, particularly of the normal members which occur naturally in petroleum, are re-arranged to the required branched structures. Such re-arrangement is a reversible first-order reaction in which at low to moderate temper. atures the equilibrium favours branched structures, but with increasing temperature the equilibrium shifts towards straight-chain structures. In the absence of catalysts the attainment of equilibrium is extremely slow even up to temperatures at which the hydrocarbons are thermally unstable, while in the presence of catalysts side-reactions become more marked as the temperature increases.

The most satisfactory catalysts for paraffin isomerization are the aluminium halides promoted by certain compounds such as hydrogen halides, alkyl halides, oxygen, water and olefins. These combina. tions are extremely active under relatively low.

- Substance of a series of lectures delivered at the Royal Institution beginning November 16 . 